\title{
How Do Populist Radical Right Parties Differentiate their Appeal? Evidence from the Media Strategy of the Hungarian Jobbik Party
}

\author{
Endre Borbáth ${ }^{1 \star(D)}$ and Theresa Gessler ${ }^{2}(D)$ \\ ${ }^{1}$ Institute of Sociology, Freie Universität Berlin, Berlin, Germany, and WZB Berlin Social Science Center, \\ Berlin, Germany and ${ }^{2}$ Department of Political Science, University of Zurich, Zurich, Switzerland \\ ${ }^{\star}$ Corresponding author. Email: endre.borbath@wzb.eu
}

(Received 7 October 2020; revised 10 May 2021; accepted 11 June 2021;

first published online 3 August 2021)

\begin{abstract}
As they become more successful, populist radical right parties face a tension between keeping their nativist credentials and moderating their appeal to gain new voters. We argue that differentiating party messages to core supporters and the wider electorate allows parties to pursue both goals. We outline and empirically illustrate the previously underexplored phenomenon of selective messaging based on the communication strategy of the Hungarian Jobbik party throughout its lifespan (2006-19) in partisan outlets, press releases and Facebook. Using a dictionary approach, we map the co-evolution of populist and nativist mobilization under conditions of supply- and demand-side changes. Our results show the decline and transformation of Jobbik's nativist appeal, and an increasing reliance on populism. The trend is not uniform; Jobbik relies on nativism as a function of targeting party identifiers or the general electorate in specific media outlets. Our findings show the importance of mapping parties' programmatic appeal across platforms and over time.
\end{abstract}

Keywords: populist radical right; media; Jobbik; nativism; populism; CEE

Populist radical right (PRR) parties are one of the most researched party families in the literature on European party competition and political conflict structures. The burgeoning literature devotes considerable attention to the disproportionate influence of PRR parties on the programmatic offering of their competitors (e.g. Hutter and Kriesi 2021), hardly explained by the moderate electoral success which members of this party family typically achieve. Yet, despite the focus on the mainstreaming of PRR appeal by other parties, we know less about the trade-offs involved in the mainstreaming of PRR parties themselves as they transform over their life cycle (Akkerman et al. 2016). This is important since understanding change in the programmatic appeal of PRR parties determines the extent to which they become less

(C) The Author(s), 2021. Published by Cambridge University Press on behalf of Government and Opposition Limited. This is an Open Access article, distributed under the terms of the Creative Commons Attribution licence (http://creativecommons.org/licenses/by/4.0/), which permits unrestricted re-use, distribution, and reproduction in any medium, provided the original work is properly cited. 
of a pariah party over time. Here, the dynamic of competition in Central and Eastern Europe (CEE) reveals more pronounced changes over time than in the more institutionalized Western European party systems (Pytlas 2019).

We focus on the role of the media which allows these parties to face the tradeoffs involved in broadening their appeal beyond their core constituency. PRR parties compete in an increasingly differentiated media environment, where online media outlets and particularly social media is growing in importance for the media diet of the citizenry. Communication research has explored the extent to which a transformed media environment and specific types of media outlets may carry or even reinforce populism and nativism (e.g. Engesser et al. 2017; Hameleers and Vliegenthart 2019; Krämer 2017; Zulianello et al. 2018) as the two key elements of the programmatic appeal of PRR parties. However, this line of literature has largely existed separately from the literature on party competition, which discusses the incentives to change party appeal.

We propose bridging the literature on party competition and political communication to explore change over time in the programmatic appeal of a PRR party throughout its life cycle: Jobbik - Movement for a Better Hungary (Jobbik Magyarországért Mozgalom). We take Jobbik as a representative case of the PRR party family in the post-communist region, an 'archetype of the populist radical right party in Central and Eastern Europe' (Pirro 2015: 106). Although initially Jobbik achieved early and exceptional success by regional standards through a nativist appeal, the party adopted a more mainstream programme soon after its entry to parliament in 2010 in the hope of increasing its electoral support. However, the success of this strategy remained limited and after the third Fidesz two-thirds electoral victory, its long-term president, Gábor Vona (2006-18) resigned in the aftermath of the 2018 elections. Since then, Jobbik has seen the rise of intra-party conflict and a decline in both its electoral support and its visibility in the press. ${ }^{1}$ Studying Jobbik in this period thus allows us to trace the party's programmatic appeal over its lifetime. The case of Jobbik illustrates the specific issues the transformation of PRR parties entails in the CEE context.

Although programmatic change is generally a risk for parties, it comes with particular challenges for PRR parties. They combine people-centred, anti-establishment rhetoric with nativism to maintain their reputation of uncompromising ideological purity (Akkerman et al. 2016). Yet, as they are confronted with isolation in the party system and reach the electoral ceiling of PRR rhetoric, it becomes appealing to adjust their message and bring it closer to the preferences of the median voter. While targeting the centre is potentially attractive to all parties in a Downsian framework (Wagner 2012), the moderation of PRR parties hinges on nativism: unlike mainstream parties that form their appeal based on a diverse set of issues without particular emphasis on any single one of them, for PRR parties, nativist issues play a key role. De-emphasizing nativism carries the risk of losing the support of their core electorate, but may allow PRR parties to achieve higher vote shares overall and eschew the stigma of a pariah party.

In previous research, change in PRR programmatic appeal is conceptualized as positional shifts across issue dimensions (Wagner and Meyer 2017), an expansion of the diversity of issues emphasized in party platforms (Bergman and Flatt 2020) or a shift in narrative frames (Pytlas 2019). Notwithstanding their merit, none of 
these approaches considers the distinction between populism and nativism important in explaining shifts in the appeal of PRR parties over time, mostly because they implicitly assume that emphasis on populist and nativist messages is part of the same dimension and the two 'move together'. The argument is most explicitly formulated by Tjitske Akkerman et al. (2016), who identify the moderation of PRR parties' nativist and populist appeal as two distinct but equally important dimensions of mainstreaming. We propose a previously underexplored mechanism, according to which the mainstreaming of the appeal of the PRR is captured by a shift in emphasis from nativism towards populism. Increasing the salience of populism to the detriment of nativism should help PRR parties to develop a more 'moderate' profile without abandoning their core electorate. In this regard, we contest the assumption that by mainstreaming their appeal, PRR parties equally abandon populist and nativist appeals. The empirical analysis of Jobbik's communication in partisan media outlets, press releases and Facebook posts illustrates that nativism simultaneously declines and transforms, allowing populism to become the defining element of the party's programmatic appeal.

Our approach innovates both substantively and methodologically. By bridging the party competition and political communication literature, we bring the focus on PRR parties and CEE party competition to the literature on political communication. We enrich the literature on party competition with the focus on media strategies and outlet-level differences in parties' programmatic appeal. Methodologically, we study this dynamic through an exceptionally long time span, from 2006 to 2019, and across different sources. To study Jobbik's appeal over time, we collected a unique data set that brings together partisan sources, press releases and Facebook posts. To our knowledge, no other analysis of the communication strategy of a PRR party to date covers a similarly long time span across a set of sources as diverse as these. We innovate on the prevalent approach in the literature, which infers party positions based on a single source, be that expert surveys or party manifestos. Using a dictionary approach to party messages, we put the agency of PRR parties at the centre of the analysis and discuss the constraints and opportunities provided by the media environment and electoral competition.

In what follows, we outline the role of the media in alleviating the tension PRR parties face as they become more successful and have to appeal to a diverse set of preferences. After introducing the type of data we analyse and our dictionary-based approach to studying the development of populist and nativist appeals, we present empirical evidence of static and over time differences between media channels, as well as the role of supply- and demand-side factors in the evolution of Jobbik's programmatic appeal. The conclusion summarizes the findings and places them in the broader literature on PRR parties.

\section{Theoretical considerations}

\section{Two models of challenger politics in CEE}

We start by introducing the distinction between what we consider the two prevalent models of challenger party politics in the CEE region (Engler et al. 2019; Kriesi 2014; Stanley 2017; Učeň 2007). The first of these models is nativist mobilization by PRR parties, the second anti-establishment mobilization by centrist populist parties. 
According to Cas Mudde (2007: 15-23), PRR parties are defined by their nativist appeal. These parties combine nativism with populism and authoritarianism, the two additional dimensions that characterize the appeal of the PRR party family. ${ }^{2}$ Nativism, as the ideology of the nation state, "holds that states should be inhabited exclusively by members of the native group ("the nation") and that non-native elements (persons and ideas) are fundamentally threatening to the homogenous nation-state' (Mudde 2007: 19). In formulating a nativist appeal, PRR parties explicitly exclude groups that they consider non-native. Although both nativism and populism are often mobilized by the same PRR actors, populism is a thin-centred ideology (for the analytical distinction between the two, see e.g. Bonikowski 2017), defined by the interaction of two distinct components: people-centrism and antielitism (Mudde 2004). People-centrism, an appeal to the 'will of the people', is an often-used trope in a range of programmatically different calls to mobilize. Here 'people' 'can refer to the common or ordinary people, the people as plebs; to the sovereign people, the people as demos; and to the culturally or ethnically distinct people, the people as nation or ethnos' (Brubaker 2017: 359). While nativism and populism might both appeal to the 'people', nativism entails a more restrictive ethnic definition of the people. Unlike nativism, populist mobilization formulates an encompassing message, without targeting or excluding groups based on prepolitical traits. Additionally, populism links people-centrism with anti-elitism by accusing elites of betraying the will of the people.

While PRR parties achieved notable success after the transition by combining nativist and populist mobilization, after EU accession a particular brand of populist mobilization emerged in the CEE region (Kriesi 2014; Stanley 2017) - so-called centrist populism (Engler et al. 2019). Centrist populist parties mobilize against the political elite as a whole, formulating an anti-elitist, pure form of populism, 'almost completely unencumbered by ideological constraints' (Učeň 2007: 54). Whereas, in the case of PRR parties, nativism acts as a host ideology and forms a well-identifiable core of their programmatic appeal, the host ideology of centrist populist parties varies considerably (Engler et al. 2019). The success of centrist populist parties in CEE demonstrates the ability of these parties to make salient use of anti-establishment/populist 'thin' supply even if they link it with 'thick' ideological appeals placed within the mainstream. PRR parties that have achieved a certain level of success but are confronted with the limited availability of new voters sympathetic to their nativist agenda might be inspired by the success of this alternative brand. One strategy to outgrow the limits of a nativist appeal is to change the 'thick' ideology of nativism while keeping the 'thin' populist elements of peoplecentric and anti-establishment mobilization intact. Such a strategy runs counter to the assumption that populism and nativism need to develop similarly in processes of moderation (e.g. Akkerman et al. 2016).

\section{Differentiated media landscape and strategic messaging}

So far, we have introduced the distinction between the two models of challenger politics in the CEE region and indicated why centrist populism might appeal to already established PRR parties. In this section, we discuss the role of the media in allowing the party to rebrand its nativist 'thick' ideology and target more centrist 
voters. We build on literature that discusses how parties communicate with voters in CEE in their attempt to augment and stabilize their electorate, a literature which has explored two different avenues. First, an increasing body of work demonstrates that parties use their organizations to communicate with voters (e.g. Tavits 2013). Second, when they communicate via media channels, parties mobilize the appeal of their candidates and organizational brand (Pirro 2015; Werkmann and Gherghina 2018). We take a step further and explain the mechanisms that lead to higher and more differentiated electoral appeals in the case of communication via the media by a PRR party.

Specifically, we argue that the segmentation between the audience of the different media outlets means that parties may formulate two different appeals simultaneously: one targeted at their core electorate, and the other at the general public. This is in line with existing qualitative evidence suggesting that parties act strategically and consider differences in the audience of platforms in their online campaigns (e.g. Kreiss et al. 2018). For PRR parties, a differentiated media landscape provides the opportunity to target audiences selectively, and simultaneously deploy nativist messages for their base while formulating an appeal to new voters with a less nativist appeal.

To understand how PRR parties build their appeal strategically, we need to enrich the purely ideational understanding of populism with the role of populist communication strategies. While the two are sometimes discussed as competing approaches to the study of populism, we consider them complementary and follow Hanspeter Kriesi (2014: 364; also see Jagers and Walgrave 2007), who argues that 'populist ideology manifests itself in the political communication strategies of populist leaders. ... As an expression of the populist ideology, populist communication strategies may be used to identify the populist ideology empirically.'

This leads us to adapt the argument about parties' strategic communication across media channels so that it emphasizes both aspects of the PRR appeal: PRR parties may weight the thin ideology of populism and the thick ideology of nativism differently in their communication on different platforms. This can be translated directly into our first expectation: the key dimension distinguishing media outlets is how far they target core supporters as opposed to the general electorate. We argue that PRR parties attempting to moderate their programmatic appeal - here Jobbik - rely on more partisan media outlets to keep their supporters on board with nativist messages. Having a firmly established presence in the relatively isolated radical right milieu allows the party also to formulate a more inclusive, populist message for the general electorate in the mainstream media. Hence, our first hypothesis is:

Hypothesis 1: The more a media channel targets the party's core supporters, the more nativist the party's communication on this channel.

In addition to static differences, our argument about media strategies as an expression of moderation entails that the shift over time is not characterized by the same trend and pace across platforms. Two different processes contribute: on the one hand, to maintain their credibility, we expect mainstreaming by PRR parties to be a gradual and continuous process that takes place over a longer time. On the other hand, maintaining the loyalty of existing voters requires regularly deploying 
nativist messages - for instance, to fire up the base before elections. This strategy should result in short-term fluctuations in the emphasis on these messages. While both the long-term trend and the fluctuation shape the level of nativism, we argue that we are most likely to observe bursts of nativist messages on platforms targeting existing supporters - for example, in partisan media outlets. In contrast, in outward communication that Jobbik engages in to change its appeal, we are more likely to see gradual and continuous change.

Hypothesis 2: The more a media channel targets the party's core supporters, the more the dynamic of nativism fluctuates.

\section{PRR parties' appeal in their electoral context}

In the previous sections, we introduced the two models of challenger politics in CEE as well as the role of a differentiated media landscape in allowing PRR parties to balance the two forms of appeal. In this section we will discuss the broader context of electoral competition to identify the incentives PRR parties face in forming and adjusting their appeal. We argue that the extent to which PRR parties maintain their nativist appeal depends on the interaction of media channels with supply- and demand-side considerations.

According to our baseline expectation, as they mature, PRR parties moderate their nativist appeal throughout their lifetime. A key moment in this regard is entry to parliament, when the institutional logic of parliamentary politics puts these parties under pressure both to take a position on a broader set of issues and to break with movement-based mobilization (Kitschelt 2006: 287). Although most successful PRR parties broaden their appeal beyond nativism (Bergman and Flatt 2020), we suggest the dynamic of the process is not only a function of their organizational features but depends on the broader context of electoral competition (Kitschelt 1989), including both supply- and demand-side factors.

We highlight two such factors that we argue shape PRR parties' media strategies. First, potential supply-side competition from another party targeting nativist voters with a programmatically proximate offer may push PRR parties to stop moderating. PRR parties are then forced to re-emphasize nativism and distinguish themselves from their competitor. This may occur because of the emergence of radical splinter parties or because centre-right parties appease the radical electorate. Here, Hungary represents an extreme case: although not having a cordon sanitaire between the mainstream and the PRR is somewhat typical for CEE (e.g. Pytlas 2019), the main centre-right party in Hungary, Fidesz, increasingly targeted nativist voters after the 2015 so-called migration crisis (Gessler et al. 2021). Notably, by 2017, Fidesz overtook Jobbik in being the party furthest to the right in the Hungarian party system in cultural terms (Pirro et al. 2019: 3). Fidesz's move was part of a longer-term strategy of accommodating some of Jobbik's proposals (Enyedi and Róna 2018; Gessler and Kyriazi 2019; Pirro 2015; Pytlas 2016), which put Jobbik under pressure to distinguish its stance from the rhetoric of the government and defend its electoral base. In this regard, being embedded in the radical right media landscape might allow Jobbik to appeal differently to its core electorate to renew its nativist reputation. Accordingly, we expect that: 
Hypothesis 3: As Fidesz becomes more nativist, Jobbik increases the salience of nativism in media channels targeting the party's core supporters.

Second, from a demand-side perspective, the appeal of PRR parties should also depend on the potential to gain new voters. With their populist appeal, PRR parties are in principle well-positioned to target voters disappointed with other parties and political elites. Distancing themselves from nativism means they can not only target right-wing but all anti-establishment voters. Here, the high level of ideological polarization (Vegetti 2019) and dissatisfaction with the government in Hungary should sustain this dynamic; public opinion polls consistently find that more voters wants a change in government than those willing to vote for the parties in opposition. This constitutes a central anti-/pro-government divide and provides particular opportunities for Jobbik, as it refused to cooperate with former governing parties of both political camps. Not being associated with past governments potentially allows Jobbik to mobilize not only voters disappointed with the government but also those who did not vote in the past. ${ }^{3}$ As we argued previously, a central strategy in this regard is to form a broad appeal in general media outlets. Consequently, we hypothesize that:

Hypothesis 4A: When the share of undecided voters is higher, Jobbik decreases the salience of nativism in media channels targeting the general electorate.

However, as Markus Wagner (2012) convincingly argues, parties evaluate demandside opportunities differently, depending on the parties' strength in the electorate. For large parties, moderate positions enable them to appeal to a wide electorate. For smaller parties such as the PRR, emphasizing issues on which they have extreme positions allows them to distinguish their profile (also see Kitschelt 1994). While Wagner does not include the media in his model of issue selection, a segmented media market allows parties to differentiate their appeal further. Thereby, parties can distinguish themselves among their supporters without necessarily alienating undecided voters. Introducing differences across media channels leads us to expect that when Jobbik is smaller, the party emphasizes nativist issues in outlets targeting its core electorate. In contrast, when Jobbik is more popular, we would expect a lesser emphasis on nativism across all media channels:

Hypothesis 4B: When the share of undecided voters is higher and Jobbik is less popular, the party is more likely to rely on its nativist message in media channels targeting its core electorate, but not in media channels targeting the general electorate.

The implications of the supply- and demand-side dynamic give rise to competing pressures on PRR media strategies. While Fidesz targeted its core electorate, Jobbik faced an increasing pressure to present a more inclusive, anti-Fidesz appeal. Faced with these countervailing forces, we argue that a differentiated media landscape allows PRR parties to 'square the circle' by tailoring their appeal to both partisan and centrist voters. In what follows we describe the media context which makes such a strategy viable in the Hungarian case. 


\section{The PRR in the Hungarian media landscape}

Compared with other CEE countries, the Hungarian media landscape is considered remarkably clientelistic (Örnebring 2012). High political dependency allowed both the left and right to establish their own media empire, for example, by dividing up available radio licences among stations loyal to them. The new media law adopted in 2010, and the restructuring of ownership in its aftermath, increased the political dependence of the media (Bajomi-Lázár 2015) and led to the dominance of right-wing media outlets. In this context, the radical right has established its own media environment independent of mainstream media outlets (Jeskó et al. 2012). The radical right media is embedded in a subcultural milieu where, next to political and infotainment media outlets, other actors are present, such as national rock bands, clothing shops and even organic food shops. To conceptualize the extent of differentiation of the radical right media network, József Jeskó et al. (2012) cite the pillarized society model of Arend Lijphart (1968). Relying on their analysis, we map the programmatic appeal of Jobbik in the two most prominent partisan media outlets.

Based on network analysis, Jeskó et al. (2012) find an isolated, self-referential radical right online network, with most websites established after 2006. They identify infotainment websites as key instruments for Jobbik to feed its messages to its supporters. Two of these websites stand out in their analysis as the source of the messages that subsequently spread in the network: Kuruc.info and Barikád.hu. Launched in 2006, Kuruc.info has been the most prominent source of hate speech in Hungary. The page features sections devoted to so-called 'Holocaust fakes', 'Roma criminality', 'anti-Hungarianism' and 'politician criminality'. Kuruc.info enjoys remarkable popularity: in 2010, it was the third-largest online political news source with around 60-90,000 unique visitors per day. Although Jobbik did not acknowledge its links to the website, the portal has been one of the most devoted allies of the party due to its affiliation with Elöd Novák, a politician in Jobbik's leadership. ${ }^{4}$ Thus, we decided to include this source, in part due to its prominence in the radical right online network, in part due to the overlap between its readership and the party's core electorate.

Unlike Kuruc.info, which has an independent identity and loyal supporters, the second website Jeskó et al. (2012) identify, Barikád.hu, was established as a party news website. Published as a weekly magazine in print between 2010 and 2017, in addition to daily online coverage, it is primarily financed by the party foundation of Jobbik. When the distance between Kuruc.info and Jobbik started to increase, Barikád.hu went through a change as well: pre-2012 posts were deleted, and the platform was rebranded as Alfahír.hu. The website has become a right-wing news site, aiming to provide a consistent flow of information to party supporters but falling short of the radicalism as well as the popularity of Kuruc.info. Its news sections and editorials feature Jobbik prominently in a positive light. Given the close connection between Alfahír.hu and the leadership of Jobbik, the party has considerable influence over what is published on this platform.

While Jobbik is only partly able to influence what is published by these sources, both Kuruc.info and Alfahír.hu represent the media channels most clearly targeting the party's core supporters. In addition to them, we also trace the programmatic 
appeal of Jobbik in the party's press releases and on Facebook. While in the press releases Jobbik targets the general electorate via the press, the target audience of social media posts is less clear. On the one hand, we may suspect that Facebook serves as a medium of direct communication (Engesser et al. 2017; Krämer 2017) between the party and its relatively young voter base. On the other hand, given the diversity of potential audiences on social media - not only sympathizers but also journalists and other media professionals - Facebook might also be a tool for the party to inform a broader audience. In the latter case, Facebook serves the same purpose as the press releases issued by Jobbik and distributed by traditional media outlets: it broadcasts the party's message to the general public.

\section{Data and methods}

We propose studying programmatic change as a shift in emphasis. More specifically, we study changes in the salience (i.e. relative emphasis) of the elements associated with the populist and nativist ideology in Jobbik's messages in different media outlets over time. While studying programmatic change based on salience neglects positional shifts, the latter are relatively unlikely to occur, especially in the case of radical parties (Hooghe and Marks 2018).

Techniques of quantitative text analysis have two advantages vis-à-vis other approaches in measuring populist and nativist communication, both of which have key importance in our research design (Meijers and Zaslove 2021). First, they are uniquely able to capture shifts in salience. Secondly, they allow us to estimate the variance between different texts, and consequently between different media outlets. Our approach builds on recent papers that use quantitative text analysis to measure issue emphasis and specifically populism with dictionaries (Bonikowski and Gidron 2016, 2019; Hameleers and Vliegenthart 2019; Harrison and Bruter 2011; Hunger 2020; Pauwels 2011; Rooduijn and Pauwels 2011). However, we go beyond existing work by, first, carefully constructing a comprehensive populism dictionary that is specific to the Hungarian context, second, by assembling a much larger text corpus that includes multiple sources and covers the party throughout its life.

We construct dictionaries to trace the three key concepts of our analysis: antielitism, people-centrism and nativism. In line with the definition of populism (see above), and with the recent literature on populism as a latent construct (e.g. Meijers and Zaslove 2021), we classify a document as populist when terms from both the anti-elitist and the people-centrist dictionary are present. We start the dictionary construction by translating the terms used in the dictionaries of the abovecited studies. We tested them by sampling texts that contained the terms. We kept only entries that were present in at least two of the corpora we examine and indeed appeared in a context associated with the concept they aim to measure. We complemented these terms with two additional sources. First, we constructed a list of terms based on the Manifesto Corpus (Merz et al. 2016): we selected all electoral manifestos by Jobbik and extracted the terms that distinguish issues close to our key concepts from other issues. ${ }^{5}$ Second, we complemented the final list with some context-specific terms, mostly referring to historical revisionism, which were not present in the previous lists or the manifestos. To validate our dictionary, 
we tested its performance against a stratified sample of 250 hand-coded documents, randomly selected from all five corpora. The dictionary is slightly better for nativism $(\mathrm{F}$ score $=0.91)$ than for populism $(\mathrm{F}$ score $=0.82)$. Online Appendix A presents the final terms and additional details on the dictionary we constructed.

To convert these documents into measures of emphasis on populism and nativism, we follow the approach of Bart Bonikowski and Noam Gidron $(2016,2019)$, and rely on a dichotomous distinction in classifying them: a document is nativist if it includes at least one word from our nativism dictionary, a document is populist if it includes at least one word each from our anti-elitism and our people-centrism dictionary. ${ }^{6}$ While less precise than a relative approach that measures the proportion of nativist words within a document, we believe the dichotomous distinction provides a more accurate assessment of the overall corpus, since it mitigates differences in the length and character of documents which we describe in the next paragraph. Although not every document that contains, for example, one of the terms associated with nativism may strictly be a 'nativist document', we believe that even occasional nativist references activate nativist ideology. In Online Appendix D we show the distribution of documents using an alternative, proportional measure.

For the actual analysis, we collected almost 60,000 documents that reflect Jobbik's communication. We obtained all articles on Kuruc.info and Alfahír.hu which mention Jobbik in the title or main text at least once. We collected all press releases the party had issued from the Hungarian national press service (Országos Sajtószolgálat), which publishes press releases by parties and organizations. In addition, we also collected all Facebook posts by the official account of the party (JobbikMagyarorszagertMozgalom) and the account of the party president Gábor Vona (vonagabor) from CrowdTangle. ${ }^{7}$ We selected the period from 1 February 2006, the time when the first press releases by Jobbik were issued and just before the party's first electoral run, up until 15 March 2019. Next to the Jobbik-specific corpora, we also collected Fidesz press releases from the same source for the same period, to test our hypothesis on supply-side dynamics. The five corpora differ in their time period, ${ }^{8}$ size and characteristics (e.g. average length of documents) ranging from roughly 3,500 posts on the Facebook page of Gábor Vona to almost 22,000 articles on Kuruc.info (see Table 1 in Online Appendix B). We believe this represents the most comprehensive analysis of Jobbik's communication so far.

Finally, we use the measures to conduct a time series cross-sectional regression analysis to explore the drivers of change. In this part of the analysis, we model the quarterly share of documents we classify as nativist. The linear model includes panel corrected standard errors (Beck and Katz 1995), and assumes a panel-specific first order auto-correlation AR(1) process, which corresponds to the lag structure of the nativism series on each platform. We include platform fixed effects and model nativism as a function of Jobbik's populism, organizational development (preparliament, in-parliament, after the migration crisis), the party's popularity (mean value of the figures from Ipsos, Medián, Publicus, Republikon, Tárki), the share of those in the electorate who indicate they have no party to vote for (mean values from Tárki and Závecz Research Center), and Fidesz's nativism based on the party's press releases. Jobbik's popularity, the share of undecided voters, and Fidesz's nativism are included with a lag. 


\section{Results}

Our key argument refers to the variation in the amount of nativist and populist messages across platforms. To test this expectation, we start by examining the level of nativism and populism based on our document classification. Figure 1 presents the average share of nativism and populism by platform:

As Figure 1 shows, the level of nativism is higher than the level of populism in all the five channels we examine, but platforms vary according to their targeting of Jobbik's core supporters. In line with H1, Jobbik is most likely to rely on its nativist appeal in the two partisan media outlets, primarily on Kuruc.info, which is somewhat more nativist than the party-funded Alfahír.hu, which in turn resembles the press releases. Facebook substantially lags behind. Populism follows the variation of nativism: it reaches its highest level in the partisan media outlets, followed by the press releases, and finally by Facebook. The low levels of nativism and populism on Facebook indicate that the party uses the social media platform to reach out to a diverse audience, which is not necessarily attracted by nativist and/or populist messages. Overall, the gap between the level of nativism and populism is smallest on Alfahír.hu.

We now turn to variation over time to test our second hypothesis. To do so, Figure 2 presents the share of documents we classify as nativist or populist, across the different platforms, over time.

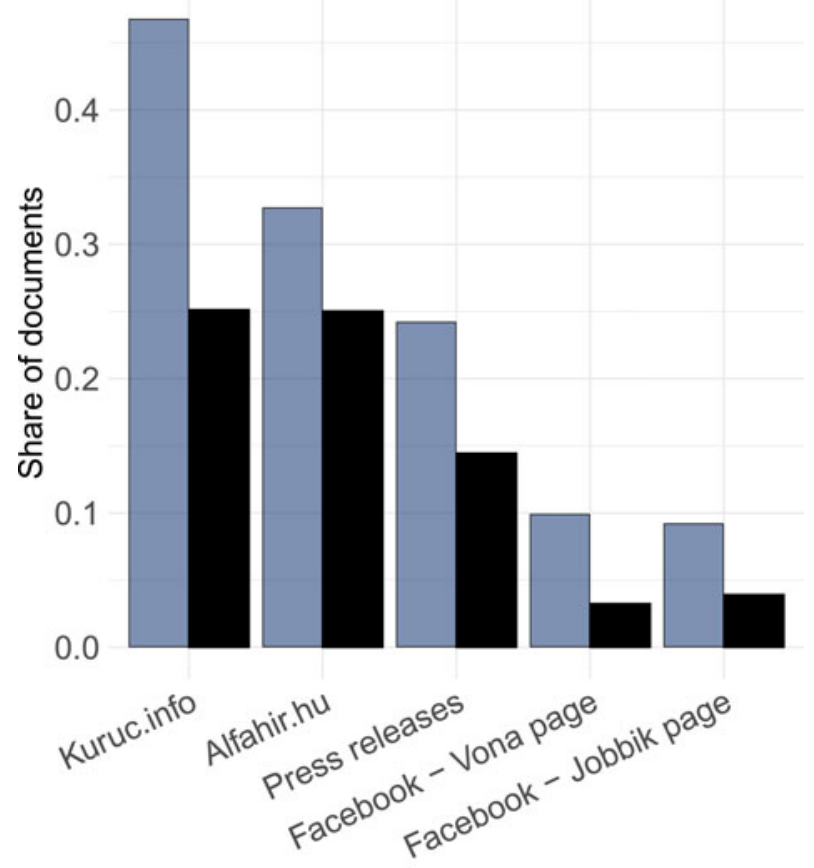

nativism $\square$ populism

Figure 1. Documents with a Nativist and Populist Appeal on Each Platform 


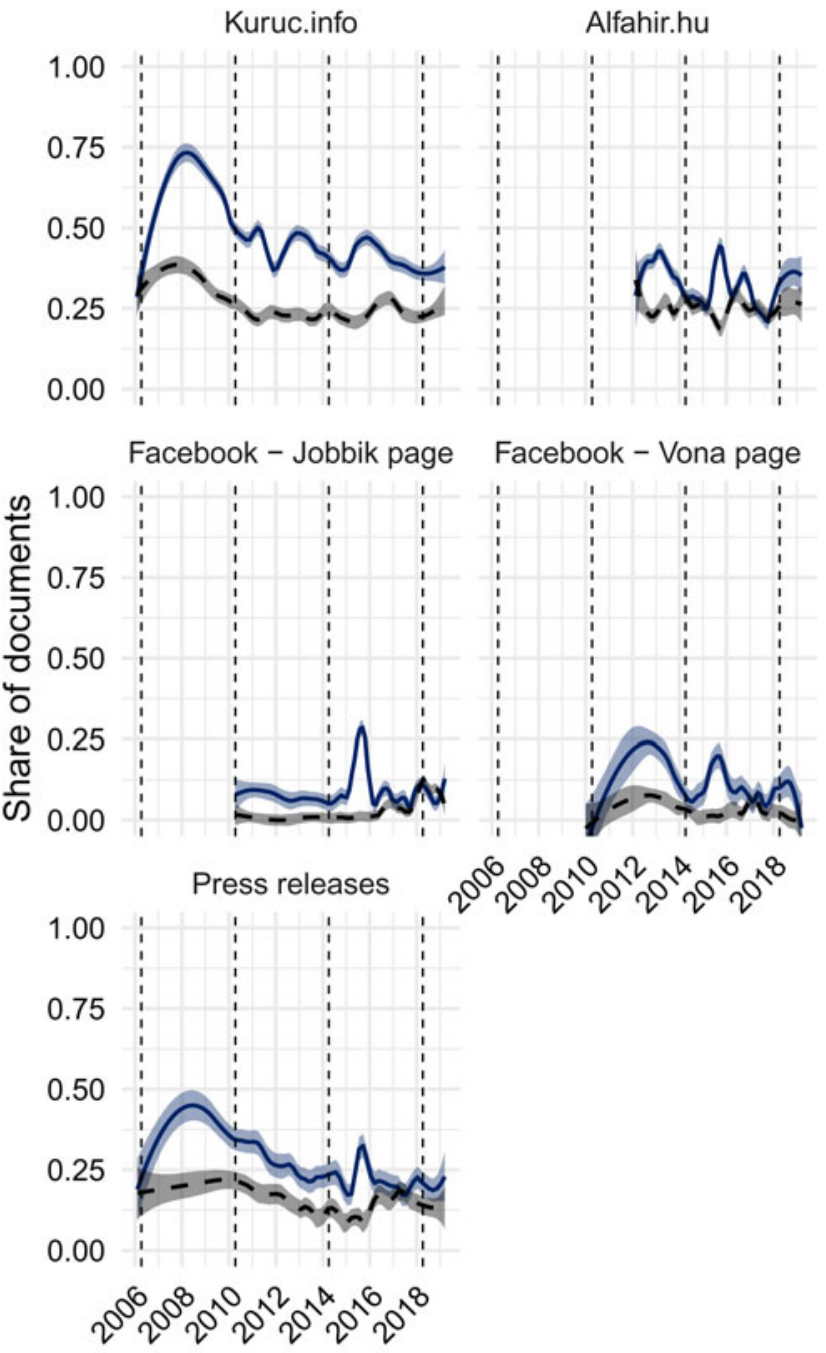

- nativism - - populism

Figure 2. The Share of Documents Over Time with a Populist or Nativist Appeal on the Different Platforms

Note: The lines represent the LOESS smoothed estimates for all documents within a corpus and its associated $95 \%$ confidence interval. The dashed vertical reference lines represent national parliamentary elections.

In line with $\mathrm{H} 2$, the two partisan media outlets and the two Facebook pages show the fluctuation of nativism and the more stable level of populism. As the coverage of Kuruc.info reveals, the extent to which Jobbik relied on nativism declined prior to entering parliament, with some shorter-term fluctuations throughout the period. Although the coverage of Alfahír.hu starts later, the pattern reveals similar short-term fluctuations of nativism, with populism less prone to 
change. This also shows that the overall level of nativism on the different platforms varies in part due to their age. On Facebook we observe more fluctuation in nativism on the account of Vona than on the official account of the party. Press releases follow a different dynamic, characterized by a gradual decline in nativist and populist mobilization followed by relative stability after parliamentary entry.

The level of nativist mobilization only partially follows the electoral calendar. Before the 2014 elections, Jobbik toned down its nativist appeal as part of a campaign to appear more moderate associated with the leadership of Vona that became known as the 'cuteness campaign'. In contrast, before the 2018 election, Jobbik (re-)mobilized its nativist appeal on Alfahír.hu and Facebook, but the pre-election rise in nativism remains more modest than the relative peak of nativist mobilization in the pre-2010 period before Jobbik entered parliament. In parliament, the peak of nativist mobilization corresponds to the so-called migration crisis in the second half of 2015. This was the period during which Fidesz took a nativist turn. Figure 3 shows Jobbik's nativism across platforms parallel with the level of nativism observed in Fidesz's press releases during the same period.

As the figure shows, during this time, Jobbik's nativism radically increases across virtually all platforms. However, the phenomenon was short-lived, and by the second half of 2016 populism and nativism became similarly important on all platforms except Kuruc.info. While we are not suggesting that Jobbik mobilized in nativist terms only for strategic reasons in response to Fidesz, the temporal overlap between the two suggests supply-side interactions at least during this brief period. ${ }^{9}$ When looking at the overall period of the evolution of Jobbik's appeal, we take the difference in the dynamic of nativism between the partisan outlets and Facebook on the one hand, and the press releases on the other hand as evidence of $\mathrm{H} 2$.

These results show that the main change in Jobbik's programmatic profile is a decrease in nativism over time. To model the drivers of this change, we now turn to the regression analysis. Table 1 shows the results of the model we introduced in the data and methods section.

Model 1 presents our baseline model. The model confirms the platform differences the descriptive analysis has shown: compared with the press releases, the level of nativism in the partisan media outlets is higher, while on Facebook it is lower. We take this as evidence of H1. The model also confirms our baseline expectation: throughout its life cycle, but particularly after the party enters parliament, the level of nativism in Jobbik's appeal declines. Controlling for these factors, the model shows that contrary to the assumption of some of the previous literature (e.g. Akkerman et al. 2016), there is no statistically significant relationship between the level of populism and nativism in Jobbik's appeal. In other words, the variation of populism does not predict the variation of nativism; the party distinguishes the two in its messages. In terms of supply and demand, the baseline model shows that Jobbik's nativism does not linearly follow Fidesz's nativism, the party's popularity or the proportion of undecided voters in the electorate.

However, the baseline model estimates average effects across all platforms. To test $\mathrm{H} 3, \mathrm{H} 4 \mathrm{~A}$ and $\mathrm{H} 4 \mathrm{~B}$, we conduct further analysis on platform-specific, differential reactions to supply- and demand-side incentives. Model 2 estimates the interaction effect between Fidesz's nativism and the platform. Although, as the model shows, Jobbik appears to be more likely to react to Fidesz's nativism on the party's 


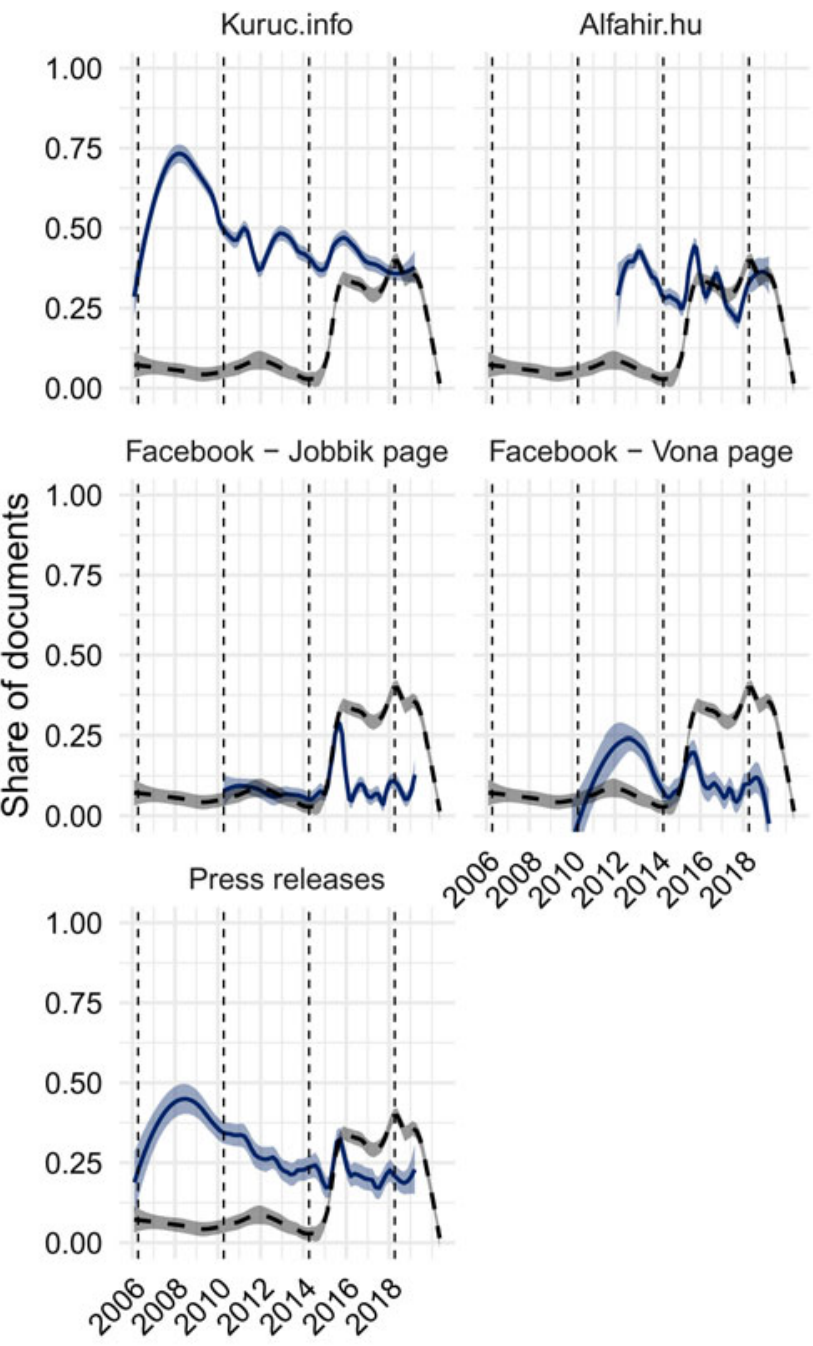

— Jobbik nativism - - - Fidesz nativism

Figure 3. Over Time Share of Documents with a Nativist Appeal on the Different Platforms Compared with the Share of Nativism in Fidesz's Press Releases

Note: The lines represent the LOESS smoothed estimates for all documents within a corpus and its associated $95 \%$ confidence interval. The dashed vertical reference lines represent national parliamentary elections.

official Facebook page than in the press releases, the size of the effect is too small to draw substantive conclusions (see the marginal effects in Online Appendix B, Figure 1). Fidesz's nativism escalates in the aftermath of the migration crisis, but as Figures 2 and 3 have already shown, Jobbik only responds with nativist mobilization for a brief period and soon returns to the previous mixture of nativist and populist messages. As a result, we are not able to confirm our supply-side hypothesis $\mathrm{H} 3$ unequivocally. 
Table 1. Level of Nativism in Jobbik's Appeal (quarterly level, TSCS regression)

\begin{tabular}{|c|c|c|c|c|}
\hline & Model 1 & Model 2 & Model 3 & Model 4 \\
\hline \multicolumn{5}{|l|}{ Data source (ref: press releases): } \\
\hline \multirow[t]{2}{*}{ Kuruc.info } & $0.15^{\star \star \star}$ & $0.14^{\star \star \star}$ & -0.06 & $-1.14^{\star \star \star}$ \\
\hline & $(10.88)$ & $(8.72)$ & $(-0.98)$ & $(-6.43)$ \\
\hline \multirow[t]{2}{*}{ Alfahír.hu } & $0.05^{\star \star}$ & 0.03 & $-0.26^{\star \star}$ & $-2.22^{\star \star}$ \\
\hline & $(2.91)$ & $(1.19)$ & $(-3.07)$ & $(-3.21)$ \\
\hline \multirow[t]{2}{*}{ FB - Jobbik page } & $-0.14^{\star \star \star}$ & $-0.19^{\star \star \star}$ & $-0.25^{\star \star}$ & $-1.48^{\star \star \star}$ \\
\hline & $(-8.28)$ & $(-8.38)$ & $(-3.09)$ & $(-4.20)$ \\
\hline \multirow[t]{2}{*}{ FB - Vona page } & $-0.14^{\star \star \star}$ & $-0.17^{\star \star \star}$ & $-0.58^{\star \star \star}$ & $-2.66^{\star \star \star}$ \\
\hline & $(-5.99)$ & $(-5.73)$ & $(-5.38)$ & $(-6.46)$ \\
\hline \multirow[t]{2}{*}{ Jobbik's populism } & 0.19 & 0.18 & 0.17 & 0.21 \\
\hline & $(1.74)$ & $(1.54)$ & $(1.58)$ & $(1.71)$ \\
\hline \multicolumn{5}{|l|}{$\begin{array}{l}\text { Jobbik's org. development } \\
\text { (ref: pre-parliament) }\end{array}$} \\
\hline \multirow[t]{2}{*}{ In parliament (> 2010q2 \& < 2015q3) } & $-0.15^{\star \star \star}$ & $-0.14^{\star \star \star}$ & $-0.16^{\star \star \star}$ & -0.08 \\
\hline & $(-3.50)$ & $(-3.39)$ & $(-3.68)$ & $(-1.71)$ \\
\hline \multirow[t]{2}{*}{ Migration crisis (> 2015q3) } & -0.11 & -0.10 & -0.11 & -0.05 \\
\hline & $(-1.82)$ & $(-1.68)$ & $(-1.92)$ & $(-0.76)$ \\
\hline \multirow[t]{2}{*}{ Jobbik's popularity (lag) } & -0.01 & -0.01 & -0.01 & $-0.14^{\star \star \star}$ \\
\hline & $(-1.70)$ & $(-1.72)$ & $(-1.53)$ & $(-3.88)$ \\
\hline \multirow[t]{2}{*}{ Proportion of undecided voters (lag) } & 0.00 & 0.00 & -0.00 & $-0.03^{\star \star \star}$ \\
\hline & $(0.43)$ & $(0.45)$ & $(-1.63)$ & $(-3.64)$ \\
\hline \multirow[t]{2}{*}{ Fidesz's nativism (lag) } & -0.13 & $-0.26^{\star}$ & -0.13 & -0.12 \\
\hline & $(-1.09)$ & $(-1.97)$ & $(-1.03)$ & $(-0.99)$ \\
\hline \multirow[t]{2}{*}{ Kuruc.info * L.Fidesz's nativism } & & 0.06 & & \\
\hline & & $(1.19)$ & & \\
\hline \multirow[t]{2}{*}{ Alfahir.hu * L.Fidesz's nativism } & & 0.13 & & \\
\hline & & $(1.44)$ & & \\
\hline \multirow[t]{2}{*}{ FB - Jobbik page * L.Fidesz's nativism } & & $0.26^{\star \star \star}$ & & \\
\hline & & $(3.69)$ & & \\
\hline \multirow[t]{2}{*}{ FB - Vona page * L.Fidesz's nativism } & & 0.20 & & \\
\hline & & $(1.79)$ & & \\
\hline \multirow[t]{2}{*}{ Kuruc.info * L.undecided_prop } & & & $0.01^{\star \star \star}$ & $0.03^{\star \star \star}$ \\
\hline & & & (3.79) & $(7.22)$ \\
\hline \multirow[t]{2}{*}{ Alfahir.hu * L.undecided_prop } & & & $0.01^{\star \star \star}$ & $0.05^{\star \star}$ \\
\hline & & & $(3.75)$ & $(3.03)$ \\
\hline
\end{tabular}


Table 1. (Continued.)

\begin{tabular}{|c|c|c|c|c|}
\hline & Model 1 & Model 2 & Model 3 & Model 4 \\
\hline \multirow[t]{2}{*}{ FB - Jobbik page * L.undecided_prop } & & & 0.00 & $0.02^{\star \star}$ \\
\hline & & & $(1.25)$ & $(2.77)$ \\
\hline \multirow[t]{2}{*}{ FB - Vona page * L.undecided_prop } & & & $0.01^{\star \star \star}$ & $0.05^{\star \star \star}$ \\
\hline & & & $(4.28)$ & $(5.23)$ \\
\hline \multirow[t]{2}{*}{ L.Jobbik's popularity * L.undecided_prop } & & & & $0.00^{\star \star}$ \\
\hline & & & & $(3.24)$ \\
\hline \multirow[t]{2}{*}{ Kuruc.info * L.Jobbik's popularity } & & & & $0.12^{\star \star \star}$ \\
\hline & & & & $(6.55)$ \\
\hline \multirow[t]{2}{*}{ Alfahir.hu * L.Jobbik's popularity } & & & & $0.20^{\star \star}$ \\
\hline & & & & $(2.98)$ \\
\hline \multirow[t]{2}{*}{ FB - Jobbik page * L.Jobbik's popularity } & & & & $0.12^{\star \star \star}$ \\
\hline & & & & $(3.52)$ \\
\hline \multirow[t]{2}{*}{ FB - Vona page * L.Jobbik's popularity } & & & & $0.21^{\star \star \star}$ \\
\hline & & & & $(5.03)$ \\
\hline \multirow{2}{*}{$\begin{array}{l}\text { Kuruc.info * L.Jobbik's popularity * } \\
\text { L.undecided_prop }\end{array}$} & & & & $-0.00^{\star \star \star}$ \\
\hline & & & & $(-6.22)$ \\
\hline \multirow{2}{*}{$\begin{array}{l}\text { Alfahir.hu * L.Jobbik's popularity * } \\
\text { L.undecided_prop }\end{array}$} & & & & $-0.00^{\star \star}$ \\
\hline & & & & $(-2.66)$ \\
\hline \multirow[t]{2}{*}{$\begin{array}{l}\text { FB - Jobbik page * L.Jobbik's popularity * } \\
\text { L.undecided_prop }\end{array}$} & & & & $-0.00^{\star}$ \\
\hline & & & & $(-2.48)$ \\
\hline \multirow[t]{2}{*}{$\begin{array}{l}\text { FB - Vona page * L.Jobbik's popularity * } \\
\text { L.undecided_prop }\end{array}$} & & & & $-0.00^{\star \star \star}$ \\
\hline & & & & $(-4.12)$ \\
\hline Observations & 193 & 193 & 193 & 193 \\
\hline r2 & 0.78 & 0.79 & 0.78 & 0.82 \\
\hline
\end{tabular}

Note: $t$ statistics in parentheses; ${ }^{\star} \mathrm{p}<0.05,{ }^{\star \star} \mathrm{p}<0.01,{ }^{\star \star \star}{ }^{\star \star} \mathrm{p}<0.001$.

To test the demand-side effects, Model 3 and Model 4 present our estimates of variation in Jobbik's reaction to undecided voters as a function of the media channel and as a function of the party's popularity. In line with H4A, Model 3 shows that the level of nativism on the partisan media outlets and Vona's Facebook page is higher than in the press releases when the share of undecided voters increases. However, the effect size is once again too small to draw substantive conclusions (see Online Appendix B, Figure 2), possibly because the relationship is also 

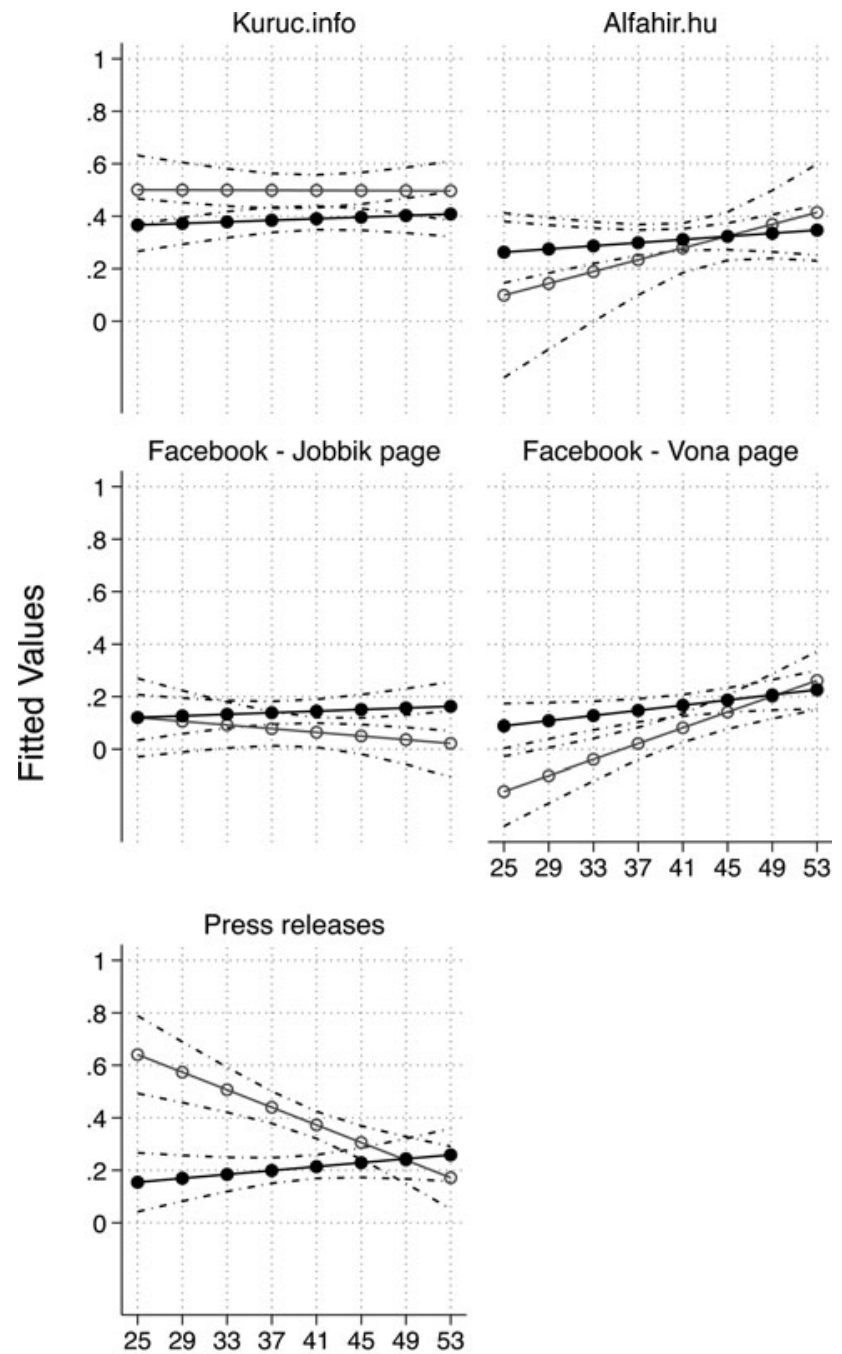

\section{Share of undecideds}

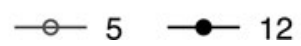

Figure 4. Marginal Effects: Jobbik's Nativism on the Different Platforms as a Function of the Share of Undecided Voters and the Party's Popularity

Note: The marginal effects figure is estimated based on the three-way interaction shown in Model 4 in Table 1.

moderated by the popularity of the party. We test $\mathrm{H} 4 \mathrm{~B}$ with a three-way interaction between the party's popularity, media channels and the share of undecided voters. As Model 4 shows, the interaction is statistically significant. To ease its interpretation, Figure 4 presents the corresponding marginal effects plots with values estimated for a popularity level of 5, respectively 12\% (the variable ranges from $0.22-15.16 \%)$, across the range of undecided voters in this period: 
In line with our hypothesis, the results show that Jobbik is more likely to adjust its level of nativism in response to the share of undecided voters when the party is smaller. Once the party's popularity reaches a certain threshold, the level of nativism becomes independent of the share of undecided voters. If the share of undecided voters increases while Jobbik is less popular, the party is not only more likely to rely on nativism on Alfahír.hu, and Vona's Facebook page, but also radically decreases nativism in the press releases to appeal to the general electorate. The gap independent of Jobbik's popularity is actually largest for the press releases, suggesting that moderation in response to undecided voters mostly happens when communicating with the wider public. On Kuruc.info and the party's Facebook page, the dynamic of nativism appears to be independent of undecided voters even when the party is small. Overall, we take this as evidence of H4B.

\section{Conclusion}

In this article, we examined programmatic change throughout the lifetime of Jobbik, one of the archetypical examples of a PRR party in CEE. As we discussed our results along with the development of the Hungarian party system over the past years, readers may have noted that the case study design limits our conclusions to the Hungarian context. The Hungarian context and the case of Jobbik allowed us to map the media strategy of a PRR that achieved its breakthrough earlier than similar parties in many other countries. Due to the formal and informal characteristics of the institutional setting (namely a strongly majoritarian electoral system and a dominant party shifting to the radical right), Jobbik confronted the dilemma of mainstreaming its appeal in starker terms than perhaps other PRR parties have to face. While this context allowed us to highlight a previously underexplored mechanism of the PRR differentiating its appeal, we believe the phenomenon is similar in other contexts. In fact, the rise of alt-right media networks in contexts as diverse as the US, Germany and Slovakia points to dynamics similar to the one we have documented.

Despite the limitations of studying the dynamic in a single case, we believe our article contributes to two strands of literatures: political communication and party competition. We believe our article makes at least two key contributions. First, we highlight the importance of platform differences for the literature on party competition. Namely, they allow PRR parties to navigate between the two models of challenger politics in CEE. Our results show that, having the opportunity to differentiate its message, Jobbik appeals to the nativism of their core supporters as well as to the populist demand among the general electorate. Contrary to previous studies, which conceptualize mainstreaming as entailing a decline of both nativism and populism as two complementary facets of the appeal of PRR parties (Akkerman et al. 2016), our results show that mainstreaming is not a uniform process, but contingent on which groups the different platforms target. The ability to rely selectively on nativist mobilization allows Jobbik to call on its core supporters, even as it moderates its nativist appeal in messages formulated for the general electorate.

Second, we outline to which factors Jobbik's differentiated emphasis on nativism responds. We highlight the role of demand and supply factors that have been less present in the literature on political communication. Our results show that despite the tremendous supply-side pressure due to the nativist turn of Fidesz, Jobbik only 
briefly mobilized in nativist terms in the aftermath of the migration crisis. We believe nativist mobilization in this period remained short-lived because, following the majoritarian incentives in the Hungarian party system, Jobbik needed to find coalition partners to compete against Fidesz. Nativism undermines its coalition potential, and maintains its status as a pariah party, whereas a shift towards centrist populism makes the party more acceptable as a partner. Generally, Jobbik appears more responsive to demand-side opportunities such as the share of undecided voters, especially in times when the party is not electorally popular. We also show that Jobbik is more likely to target undecided voters in non-nativist terms on those platforms where the party formulates an appeal to the general electorate.

Our analysis shows that even prototypical PRR parties, such as Jobbik once was, change their appeal in response to a combination of supply- and demand-side incentives. However, we do not believe that Jobbik has become a moderate party that has left its nativist agenda behind. On the contrary, we show that nativism lives on in media channels targeting its core electorate and its fluctuations show that it is regularly deployed to mobilize its base. Nevertheless, strategic reasons push the party to rely increasingly on populism at the expense of nativist mobilization. While this move came with electoral costs for the party's popularity (see Online Appendix B, Figure 3), it was sufficient for it to become accepted as a member of a broad opposition coalition targeting Fidesz and thereby helped Jobbik to overcome its pariah status. One should, however, note that the party has not (yet) been in government, therefore a definite judgement on the extent to which it has abandoned its nativist ideas cannot yet be cast.

Overall, we hope the conceptual apparatus and the methodological approach this article puts forward - namely the study of parties' programmatic appeal across multiple platforms and over a long period of time - will provide a helpful resource for future research that considers additional cases and builds on our arguments.

Supplementary material. To view the supplementary material for this article, please visit https://oi.org/ 10.1017/gov.2021.28.

Acknowledgements. We are grateful to Andrea Ceron, Katjana Gattermann, Sophia Hunger, Swen Hutter, Matthias Kaltenegger, Seongcheol Kim, Heike Klüver, Andrea Pirro, Matthew Stenberg, Kristóf Szombati, the anonymous reviewers and participants at workshops and conferences for helpful comments on previous versions of this article. We presented earlier versions at a symposium organized by Cosmos in Florence, at the Party Congress Research Group Workshop in Glasgow, at the Political Science Colloquium of the Freie Universität in Berlin, at the Berlin Brandenburg Political Behavior Colloquium and at the European Politics Working Group of the University of California, Berkeley. Endre Borbáth would also like to acknowledge funding by the Volkswagen Foundation.

\section{Notes}

1 As part of the intra-party conflict, a more radical, nativist group left the party and established the Our Homeland Movement.

2 The authoritarianism dimension defines PRR parties' attitude towards democracy and governance (Kriesi 2014; Mudde 2007). Since it is less related to the party's programmatic appeal, we focus on the other two dimensions. For a discussion of the authoritarian dimension in the case of Jobbik, see Kreko and Juhász (2017), Pirro (2015) and Pytlas (2016).

3 The reservoir of non-voters is relatively large: electoral turnout varies, but since 1990 about $30 \%$ of the electorate stayed away from the polls in each parliamentary election. 
4 Due to the party's ideological moderation, Novák left the party in the aftermath of the 2018 national election, and with his departure, the unconditional support Kuruc.info had provided to Jobbik also reduced. 5 These are: democracy, political corruption, political authority, national way of life and multiculturalism. 6 We do not conceptualize populism and nativism as mutually exclusive categories. In our approach, a document can be both populist and nativist, and as Online Appendix A, Figure 1, and Online Appendix B, Table 1, show, a portion of the documents contain references to both.

7 We exclude Facebook posts below 100 characters since they often only contain a link, video or picture without a context. Note that this is still a relatively low threshold as the shortest document we include contains only 13 words.

8 Kuruc.info and the press releases go back to February 2006, Alfahír.hu starts in February 2012, the Facebook page of Vona starts in March 2010, the official Facebook page starts in October 2010.

9 As further evidence we also looked at content-based transformation of nativism and populism. After the migration crisis, the tone of nativist mobilization changes. Jobbik shifts away from anti-Roma to antimigrant mobilization. In terms of populism, there is a steady increase in anti-elitism between 2014 and 2018, while people-centrism stays relatively constant over time. See Online Appendix C.

\section{References}

Akkerman T, Lange SL de and Rooduijn M (eds) (2016) Radical Right-Wing Populist Parties in Western Europe: Into the Mainstream? Abingdon: Routledge.

Bajomi-Lázár P (2015) Variations in Media Freedom: Why do Some Governments in Central and Eastern Europe Respect Media Freedom More than Other Ones? Central European Journal of Communication 8(14), 4-20.

Beck N and Katz JN (1995) What to Do (and Not to Do) with Time-Series Cross-Section Data. American Political Science Review 89(3), 634-647. https://doi.org/10.2307/2082979.

Bergman ME and Flatt H (2020) Issue Diversification: Which Niche Parties Can Succeed Electorally by Broadening their Agenda? Political Studies 68(3), 710-730. https://doi.org/10.1177\%2F0032321719865538.

Bonikowski B (2017) Ethno-Nationalist Populism and the Mobilization of Collective Resentment. British Journal of Sociology 68(S1), 181-213. https://doi.org/10.1111/1468-4446.12325.

Bonikowski B and Gidron N (2016) The Populist Style in American Politics: Presidential Campaign Rhetoric, 1952-1996. Social Forces 94, 1593-1621. https://doi.org/10.1093/sf/sov120.

Bonikowski B and Gidron N (2019) Populism in Legislative Discourse: Evidence from the European Parliament, 1999-2004. Working paper. https://scholar.harvard.edu/files/bonikowski/files/bonikowski_ and_gidron_-_populist_claims-making_in_legislative_discourse.pdf.

Brubaker R (2017) Why Populism? Theory and Society 46(5), 357-385. https://doi.org/10.1007/s11186017-9301-7.

Engesser S, Fawzi N and Larsson AO (2017) Populist Online Communication: Introduction to the Special Issue. Information, Communication and Society 20(9), 1279-1292. https://doi.org/10.1080/1369118X. 2017.1328525.

Engler S, Pytlas B and Deegan-Krause K (2019) Assessing the Diversity of Anti-Establishment and Populist Politics in Central and Eastern Europe. West European Politics 42(6), 1310-1336. https://doi. org/10.1080/01402382.2019.1596696.

Enyedi Z and Róna D (2018) Governmental and Oppositional Populism: Competition and Division of Labour. In Wolinetz S and Zaslove A (eds), Absorbing the Blow: The Impact of Populist Parties on European Party Systems. Colchester: ECPR Press, pp. 251-272.

Gessler T and Kyriazi A (2019) Hungary - A Hungarian Crisis or Just a Crisis in Hungary? In Hutter S and Kriesi H (eds), European Party Politics in Times of Crises. Cambridge: Cambridge University Press, pp. 167-188.

Gessler T, Tóth G and Wachs J (2021) No Country for Asylum Seekers? How Short-Term Exposure to Refugees Influences Attitudes and Voting Behavior in Hungary. Political Behavior, published early online, February. https://doi.org/10.1007/s11109-021-09682-1.

Hameleers M and Vliegenthart R (2019) The Rise of a Populist Zeitgeist? A Content Analysis of Populist Media Coverage in Newspapers Published between 1990 and 2017. Journalism Studies, published early online, May. https://doi.org/10.1080/1461670X.2019.1620114. 
Harrison S and Bruter M (2011) Mapping Extreme Right Ideology: An Empirical Geography of the European Extreme Right. Houndmills: Palgrave Macmillan.

Hooghe L and Marks G (2018) Cleavage Theory Meets Europe's Crises: Lipset, Rokkan, and the Transnational Cleavage. Journal of European Public Policy 25(1), 109-135. https://doi.org/10.1080/ 13501763.2017.1310279.

Hunger S (2020) Is There a Populist Zeitgeist? Coming to Grips with an Elusive Phenomenon. PhD thesis. Florence: European University Institute. https://doi.org/10.2870/454846.

Hutter S and Kriesi H (2021) Politicising Immigration in Times of Crisis. Journal of Ethnic and Migration Studies, published online early, February. https://doi.org/10.1080/1369183X.2020.1853902.

Jagers J and Walgrave S (2007) Populism as Political Communication Style: An Empirical Study of Political Parties' Discourse in Belgium. European Journal of Political Research 46(3), 319-345. https:// doi.org/10.1111/j.1475-6765.2006.00690.x.

Jeskó J, Bakó J and Tóth Z (2012) A radikális jobboldal webes hálózatai (Jobbik: Egy network-párt természetrajza) [The Online Networks of the Radical-right (Jobbik: The Image of a Network Party)]. Politikatudományi Szemle XXI(1), 81-101.

Kitschelt H (1989) The Logics of Party Formation: Ecological Politics in Belgium and West Germany. Ithaca, NY: Cornell University Press.

Kitschelt H (1994) The Transformation of European Social Democracy. Cambridge: Cambridge University Press.

Kitschelt H (2006) Movement Parties. In Katz RS and Crotty WJ (eds), Handbook of Party Politics. Thousand Oaks, CA: Sage, pp. 278-290.

Krämer B (2017) Populist Online Practices: The Function of the Internet in Right-Wing Populism. Information, Communication and Society 20(9), 1293-1309. https://doi.org/10.1080/1369118X.2017.1328520.

Kreiss D, Lawrence RG and McGregor SC (2018) In Their Own Words: Political Practitioner Accounts of Candidates, Audiences, Affordances, Genres, and Timing in Strategic Social Media Use. Political Communication 35(1), 8-31. https://doi.org/10.1080/10584609.2017.1334727.

Krekó P and Juhász A (2017) The Hungarian Far Right: Social Demand, Political Supply, and International Context. Stuttgart: Ibidem-Verlag.

Kriesi H (2014) The Populist Challenge. West European Politics 37(2), 361-378. https://doi.org/10.1080/ 01402382.2014.887879.

Lijphart A (1968) The Politics of Accommodation: Pluralism and Democracy in the Netherlands. Berkeley, CA: University of California Press.

Meijers MJ and Zaslove A (2021) Measuring Populism in Political Parties: Appraisal of a New Approach. Comparative Political Studies 54(2), 372-407. https://doi.org/10.1177/0010414020938081.

Merz N, Regel S and Lewandowski J (2016) The Manifesto Corpus: A New Resource for Research on Political Parties and Quantitative Text Analysis. Research and Politics 3(2), 1-8. https://doi.org/10. $1177 / 2053168016643346$.

Mudde C (2004) The Populist Zeitgeist. Government and Opposition: An International Journal of Comparative Politics 39(4), 541-563. https://doi.org/10.1111/j.1477-7053.2004.00135.x.

Mudde C (2007) Populist Radical Right Parties in Europe. Cambridge: Cambridge University Press.

Örnebring H (2012) Clientelism, Elites, and the Media in Central and Eastern Europe. International Journal of Press/Politics 17(4), 497-515. https://doi.org/10.1177/1940161212454329.

Pauwels T (2011) Measuring Populism: A Quantitative Text Analysis of Party Literature in Belgium. Journal of Elections, Public Opinion and Parties 21(1), 97-119. https://doi.org/10.1080/17457289.2011. 539483.

Pirro A (2015) The Populist Radical Right in Central and Eastern Europe: Ideology, Impact, and Electoral Performance. Abingdon: Routledge.

Pirro A et al. (2019) Close Ever, Distant Never? Integrating Protest Event and Social Network Approaches into the Transformation of the Hungarian Far Right. Party Politics, published early online, July. https:// doi.org/10.1177\%2F1354068819863624.

Pytlas B (2016) Radical Right Parties in Central and Eastern Europe: Mainstream Party Competition and Electoral Fortune. Abingdon: Routledge.

Pytlas B (2019) Populist Radical Right Mainstreaming and Challenges to Democracy in an Enlarged Europe. In Herman LE and Muldoon J (eds), Trumping the Mainstream: The Conquest of Democratic Politics by the Populist Radical Right (Illustrated edition) Abingdon: Routledge, pp. 165-184. 
Rooduijn M and Pauwels T (2011) Measuring Populism: Comparing Two Methods of Content Analysis. West European Politics 34(6), 1272-1283. https://doi.org/10.1080/01402382.2011.616665.

Stanley B (2017) Populism in Central and Eastern Europe. In Kaltwasser CR et al. (eds), The Oxford Handbook of Populism. Oxford: Oxford University Press, pp. 140-161.

Tavits M (2013) Post-Communist Democracies and Party Organization. Cambridge: Cambridge University Press.

Učeň $\mathbf{P}$ (2007) Parties, Populism, and Anti-Establishment Politics in East Central Europe. SAIS Review of International Affairs 27(1), 49-62. https://doi.org/10.1353/sais.2007.0021.

Vegetti F (2019) The Political Nature of Ideological Polarization: The Case of Hungary. Annals of the American Academy of Political and Social Science 681(1), 78-96. https://doi.org/10.1177/ 0002716218813895.

Wagner M (2012) When do Parties Emphasise Extreme Positions? How Strategic Incentives for Policy Differentiation Influence Issue Importance. European Journal of Political Research 51(1), 64-88. https://doi.org/10.1111/j.1475-6765.2011.01989.x.

Wagner M and Meyer TM (2017) The Radical Right as Niche Parties? The Ideological Landscape of Party Systems in Western Europe, 1980-2014. Political Studies 65(1 suppl.), 84-107. https://doi.org/10.1177/ 0032321716639065.

Werkmann C and Gherghina S (2018) Organized for Parliament? Explaining the Electoral Success of Radical Right Parties in Post-Communist Europe. Government and Opposition: An International Journal of Comparative Politics 53(3), 461-485. https://doi.org/10.1017/gov.2016.38.

Zulianello M, Albertini A and Ceccobelli D (2018) A Populist Zeitgeist? The Communication Strategies of Western and Latin American Political Leaders on Facebook. International Journal of Press/Politics 23(4), 439-457. https://doi.org/10.1177/1940161218783836.

Cite this article: Borbáth E, Gessler T (2023). How Do Populist Radical Right Parties Differentiate their Appeal? Evidence from the Media Strategy of the Hungarian Jobbik Party. Government and Opposition: An International Journal of Comparative Politics 58, 84-105. https://doi.org/10.1017/gov.2021.28 